\title{
Graham Huggan and Helen Tiffin, Postcolonial Ecocriticism: Literature, Animals, Environment
}

Travis V. Mason

\section{Q OpenEdition}

1 Journals

Electronic version

URL: https://journals.openedition.org/ces/5990

DOI: $10.4000 /$ ces.5990

ISSN: 2534-6695

Publisher

SEPC (Société d'études des pays du Commonwealth)

\section{Printed version}

Date of publication: 1 April 2012

Number of pages: 105-106

ISSN: 2270-0633

\section{Electronic reference}

Travis V. Mason, "Graham Huggan and Helen Tiffin, Postcolonial Ecocriticism: Literature, Animals, Environment", Commonwealth Essays and Studies [Online], 34.2 | 2012, Online since 19 April 2021, connection on 23 July 2021. URL: http://journals.openedition.org/ces/5990 ; DOI: https://doi.org/ $10.4000 /$ ces.5990

This text was automatically generated on 23 July 2021 .

\section{(c) $(1)$}

Commonwealth Essays and Studies is licensed under a Licence Creative Commons Attribution - Pas d'Utilisation Commerciale - Pas de Modification 4.0 International. 


\title{
Graham Huggan and Helen Tiffin, Postcolonial Ecocriticism: Literature, Animals, Environment
}

\author{
Travis V. Mason
}

\section{REFERENCES}

Graham Huggan and Helen Tiffin. Postcolonial Ecocriticism: Literature, Animals, Environment. London: Routledge, 2010. 250 p. ISBN (pb): 978-0-415-34458-6, £20.99; (eb): 978-0-203-49817-0

1 It makes sense that the first critical introduction to postcolonial ecocriticism is a collaborative effort by Graham Huggan and Helen Tiffin. Both authors have established influential profiles as postcolonial theorists whose work is recognized and cited internationally, and both have been at the front of the nascent field of green postcolonialism. Huggan's “'Greening' Postcolonialism: Ecocritical Perspectives," published in 2004, explicitly engages two distinctive fields and demonstrates how they relate in a cross-cultural context, while Tiffin's “Unjust Relations: Post-Colonialism and the Species Boundary" from 2001 brings concerns for nonhuman animals to bear on decades of culturally and socially minded work. Together, they edited a special "Green Postcolonialism" issue of Interventions in 2007 (which includes a contribution from Susie O’Brien, whose 2001 article "Articulating a World of Difference: Ecocriticism, Postcolonialism, and Globalization" is another foundational touchstone). Familiarity with this concise and highly relevant book from the new century's first decade should reveal few surprises.

2 The introduction identifies fraught tensions among "the burgeoning alliance between postcolonial and environmental studies," beginning with seemingly obvious congruence - empire and colonization have always affected people and land - and perceived division - postcolonialism is predominantly anthropocentric, and 
ecocriticism patently ecocentric. Reconciling this tension is not the purpose of this book; rather, a focus on how the tension plays out in historical, cultural (literary), ethical/political, and biological ways shapes the book's agenda. If the subtitle, "Literature, Animals, Environment," reveals the paradoxically inclusive yet limiting purview of "postcolonial ecocriticism," its two sections seek to engage the paradox by dividing attention between the environment and zoocriticism (a more philosophically and scientifically based approach to animal studies than most ecocritics have produced).

"Development" and "Entitlement" provide Part One with its organizational structure. Huggan and Tiffin posit "[o]ne of the central tasks of postcolonial ecocriticism" as contesting "western ideologies of development" (27). A concise overview of development as a product of post-World War Two and Cold War decolonization efforts situates critiques of "developmentalism" - anthropologist Arturo Escobar's term, which overtly links discursive strategies to economic/neo-colonial practices in the Third World - squarely in a social-scientific realm. Such an orientation enriches a literary criticism attuned to postcolonial-ecocritical critics and writers whose writing aspires to enact and/or inspire activist precepts. Sensitive both to the perceived advocacy of certain authors and to the aesthetic qualities of their texts, Huggan and Tiffin remind us that "postcolonial ecocriticism is that form of criticism which appreciates the enduring non-instrumentality of environmental writing, as well as gauging its continuing usefulness in mobilizing individual and collective support" (33). Arundhati Roy and Ken Saro-Wiwa exemplify the kind of activist writing that upsets the reductive binarism - writers are intellectual, activists are practical - implied by the label writeractivist. The most effective writers operating within this aesthetic-activist genre tend to avoid reinforcing binaries and instead draw attention to "the often flagrant human and environmental abuses that continue to be practiced" in the name of development, tourism, and capitalism (77). Huggan and Tiffin examine the grounds on which development discourse rests (and faces critique) in the following chapter. Entitlement embodies colonial notions of being on the land, of possessing it, as distinct from a sense of being of/from the land, of belonging (to it). Pastoral works come to represent - even while disguising - a "crisis of ownership" that invites critical awareness of "the tension between ownership and belonging" (85) in the postcolonial world.

Much of this book's strength lies in the extended analyses of fiction and poetry, the bulk of which appears after the theoretical and political context for the chapter has been established. While many of the texts discussed have become foundational themselves, the frame within which Huggan and Tiffin set, say, Coetzee's Disgrace, Gordimer's The Conservationist, Ihimaera's The Whale Rider, and King's Green Grass, Running Water, which often means aligning them with less familiar texts, invigorates the material.

5 A similar juxtaposition dominates Part Two, which focuses on depictions of nonhuman animals. In keeping with the two-pronged approach, this section works through the ways the Western intellectual tradition has equated othered human with the less than human other as part of the colonial project while challenging the ways nonhuman animals occupy certain texts as living beings to be considered seriously and compassionately. Canonical texts include Heart of Darkness, Robinson Crusoe, and The Tempest, while more recent touchstones - those that tend to unsettle Cartesian-based assumptions - include Barbara Gowdy's elephant epic The White Bone, Yann Martel's Life 
of Pi, and Peter Goldsworthy's Wish. That I could easily go on listing more authors both those familiar to postcolonialists and ecocritics alike and those yet to achieve wide critical coverage - attests to Huggan and Tiffin's comprehensiveness. The zoocritical chapters address such concerns as carnivory, cannibalism, and sex, and the breadth on display invites readers of the book to deepen their engagement with those texts mentioned in asides and notes. The extensive bibliography offers an essential resource for carrying on with the task. It is a task as important as any critical - cultural and scientific - project facing scholars today, particularly if we are to confront in any meaningful way what the authors identify as the alienation "human beings have paid for [our] increasing control and [mis]management of nature" (203). As writers and theorists have begun the project not so much in earnest as with the hope of enacting change, so readers of Postcolonial Ecocriticism might listen to and look at the world through a hopeful, if damning, lens.

\section{AUTHORS}

\section{TRAVIS V. MASON}

Travis V. MASON has taught Canadian Studies and English in Halifax and Vancouver. After completing a PhD at The University of British Columbia, he undertook a Mellon and a Killam Postdoctoral Fellowship at Rhodes University, South Africa, and Dalhousie University, respectively. In addition to articles on Canadian and postcolonial writing, ecocriticism, and poetry, he has a book on ecocriticism and Don McKay forthcoming from Wilfrid Laurier University Press. He is at work on a public poetics project with Erin Wunker and on research related to literary responses to science in Canada. 